\title{
Clinical findings of the phakomatoses: Sturge-Weber syndrome
}

Mark Quigg, MD, MSc; Robert S. Rust, MD; and James Q. Miller, MD†
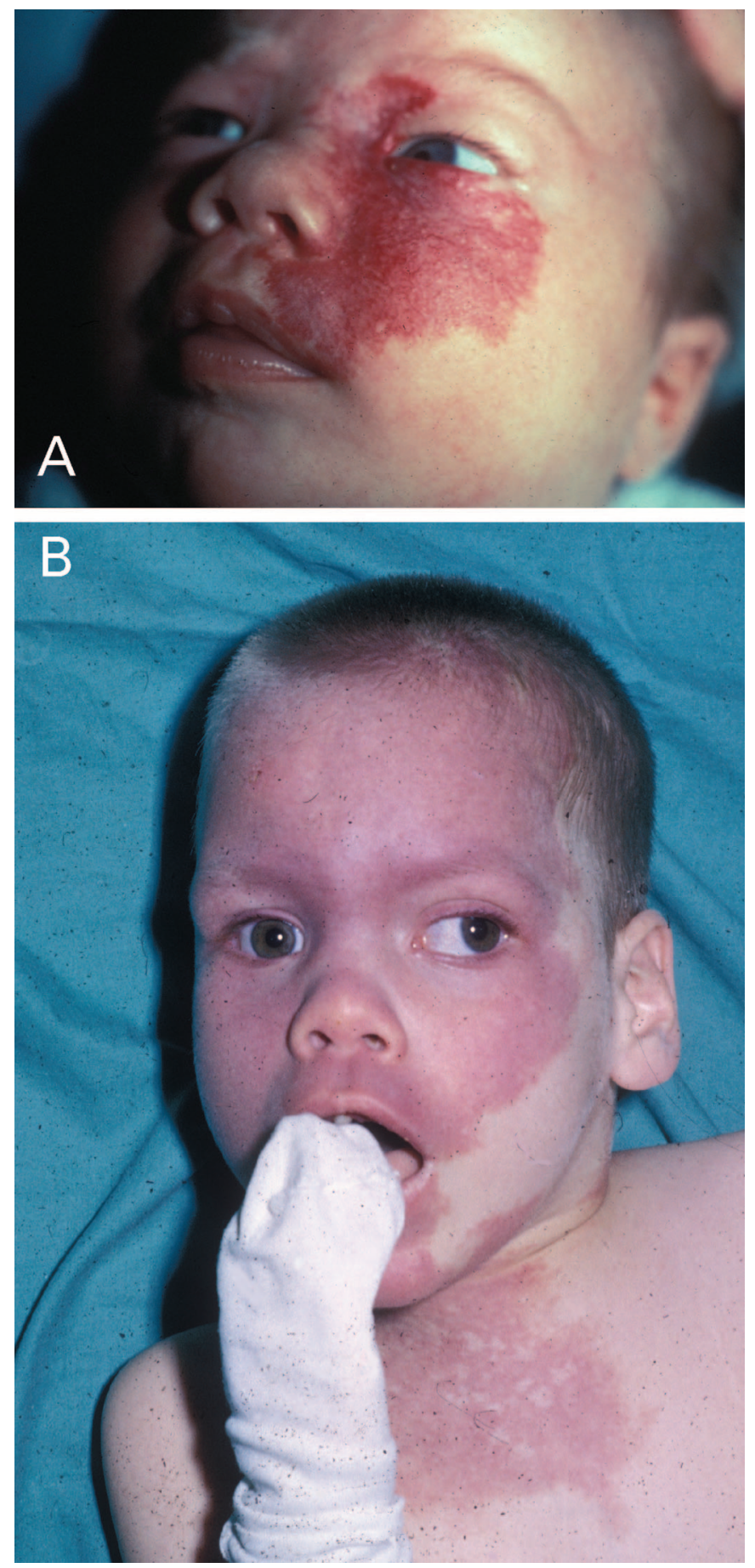

Figure 1. (A) Ophthalmic port-wine stain (PWS) in an infant. Glaucoma is a frequent complication. PWS that spares ophthalmic trigeminal distribution is usually not indicative of underlying Sturge-Weber syndrome. ${ }^{1}$ (B) Bilateral or more lower facial involvement occurs in $15 \% .^{1}$ As in this child, about half have an extracranial nevus that typically respects segmental anatomy. 

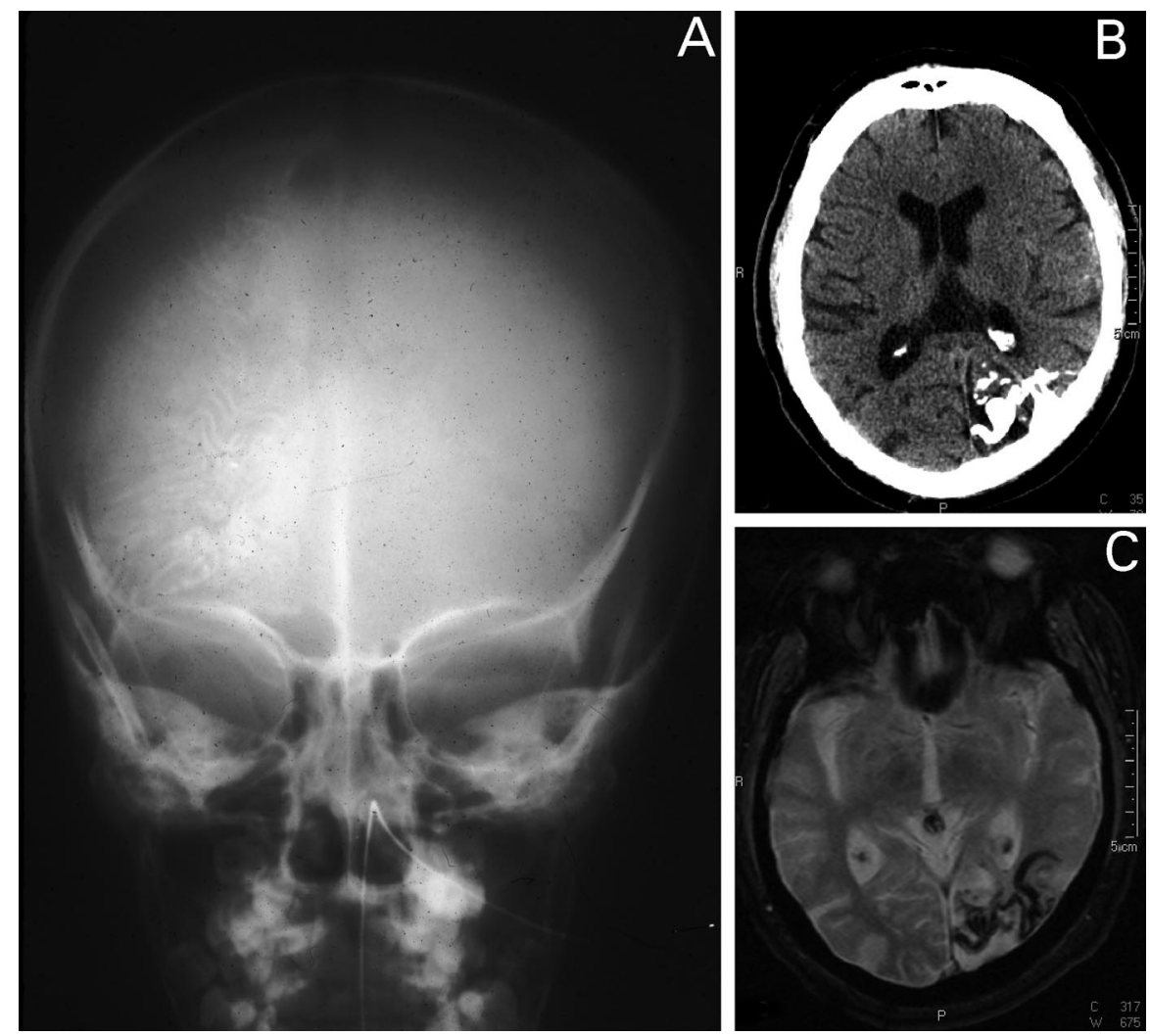

The dermatologic hallmark of Sturge-Weber syndrome (SWS) is the nevus flammeus (port-wine stain, PWS), a angiomatous lesion usually distributed in the region innervated by the ophthalmic branch of the trigeminal nerve ${ }^{1}$ caused by lack of normal regression of embryonic vascular plexus of the cephalic neural tube. The variable constellation of clinical findings of hemiparesis, mental retardation, and epilepsy is caused by the resulting leptomeningeal and cortical angiomatosis and calcification. SWS is a congenital and nonhereditary disorder. Physical findings of SWS are shown in figure 1 and neuroimaging in figure 2.
Figure 2. (A) A-P skull film that demonstrates the gyral calcifications of the subarachnoid angiomas of Sturge-Weber syndrome, tortuous parallel "tram tracks" across most of the right hemisphere. (B) In another patient, uncontrasted axial $C T$ and $(C)$ gradient-echo axial MRI show gyral calcifications, atrophy, and gliosis of the underlying cortex due to leptomeningeal involvement.

From the Department of Neurology, University of Virginia, Charlottesville.

\section{Acknowledgment}

The authors thank C. Douglas Phillips of the Division of Neuroradiology for his contributions of MRI images.

\section{Reference}

1. Tallman B, Tan OT, Morelli JG, et al. Location of port-wine stains and the likelihood of ophthalmic and/or central nervous system complications. Pediatrics 1991;87:323-327.

$\dagger$ Deceased.

Disclosure: The authors report no conflicts of interest.

Address correspondence and reprint requests to Dr. Mark Quigg, Department of Neurology, Box 800394, Health Sciences Center, University of Virginia, Charlottesville, VA 22908; e-mail: quigg@virginia.edu 


\section{Neurology}

\section{Clinical findings of the phakomatoses: Sturge-Weber syndrome Mark Quigg, Robert S. Rust and James Q. Miller Neurology 2006;66;E17-E18 \\ DOI 10.1212/01.wnl.0000197789.72780.a9}

This information is current as of February 27, 2006

\section{Updated Information \& Services}

\section{References}

Subspecialty Collections

Permissions \& Licensing

Reprints including high resolution figures, can be found at: http://n.neurology.org/content/66/4/E17.full

This article cites 1 articles, 0 of which you can access for free at: http://n.neurology.org/content/66/4/E17.full\#ref-list-1

This article, along with others on similar topics, appears in the following collection(s):

All Epilepsy/Seizures

http://n.neurology.org/cgi/collection/all_epilepsy_seizures All Imaging

http://n.neurology.org/cgi/collection/all_imaging

MRI

http://n.neurology.org/cgi/collection/mri

Other neurocutaneous disorders

http://n.neurology.org/cgi/collection/other_neurocutaneous_disorders

Information about reproducing this article in parts (figures,tables) or in its entirety can be found online at:

http://www.neurology.org/about/about_the_journal\#permissions

Information about ordering reprints can be found online:

http://n.neurology.org/subscribers/advertise

Neurology ${ }^{\circledR}$ is the official journal of the American Academy of Neurology. Published continuously since 1951, it is now a weekly with 48 issues per year. Copyright. All rights reserved. Print ISSN: 0028-3878. Online ISSN: 1526-632X.

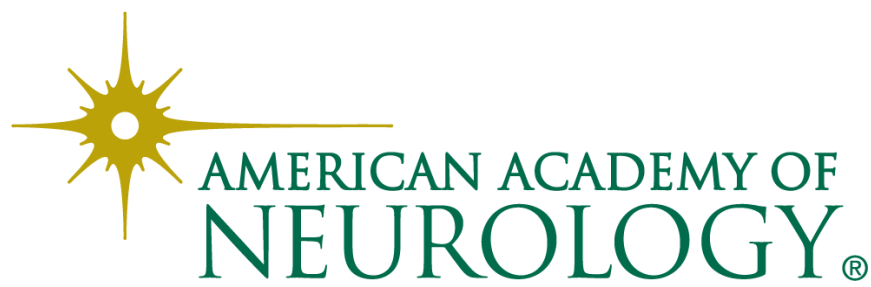

